\title{
Educational Research for BIM Technology in Applied Architecture Engineering Undergraduate
}

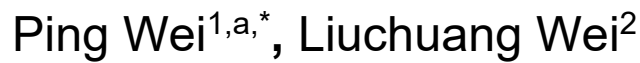 \\ ${ }^{1}$ Faculty of Architectural Engineering, Kunming University, Yunnan Kunming 650214, China \\ ${ }^{2}$ Faculty of Mechanical and Electrical Engineering, Kunming University, Yunnan Kunming 650214, \\ China \\ aweiping1123@126.com \\ ${ }^{*}$ Corresponding author
}

Keywords: BIM technology; application-oriented; construction engineering; undergraduate course; Educational research.

\begin{abstract}
BIM technology leads the construction industry in the future, conforms to the national vocational education development strategy, conforms to the Ministry of Housing and Construction's long-term plan for the construction industry, and promotes the reform of undergraduate education in Applied Construction engineering. BIM technology "three-dimensional modeling as the core work mode" is the focus of teaching reform of Applied Architecture Engineering Undergraduate course. Through the orientation of training program, the reform of graphics curriculum system, the support of professional curriculum system, the construction of professional groups, the joint graduation design and the establishment of BIM technology studio, the educational concept of "student-centered" is realized, the application of production, teaching and research is deepened, and the construction industry is promoted. To cultivate high-end technical talents who can meet the requirements of enterprises and have innovative ability.
\end{abstract}

\section{Introduction}

The full name of BIM is "Building Information Modeling", which is a new technology for the intersection of architecture and computer science. The BIM model contains all the information, functional requirements and performance of different professions. BIM technology integrates an engineering project, including the design process, the construction process, and the entire process and life cycle information, into a three-dimensional model of the building. Designers can perform visual model design, information model design, digital model design, parametric model design, and collaborative work. BIM technology is the future direction of the construction industry.

In February 2019, the State Council issued the "Notice on the Implementation of the National Vocational Education Reform" to propose the requirements for improving the high-level applied talent training system. The document puts forward a modern vocational education system with equal emphasis on education and training, develops career-oriented orientation, focuses on practical ability training, and initiates specific opinions on the pilot work of the $1+\mathrm{X}$ certification system. BIM technology adapts to the national development strategy and is an opportunity for the transformation and development of applied construction engineering. BIM technology promotes the "three-dimensional modeling as the core working mode" of the BIM technology of applied engineering under the traditional two-dimensional mapping concept. It is the national talent modernization 2035 and the future development needs of the construction industry.

\section{Ministry of housing and construction's guidance on BIM technology in construction industry}

The Ministry of Housing and Construction's guidance on BIM technology in the construction industry is shown in Figure 1. 


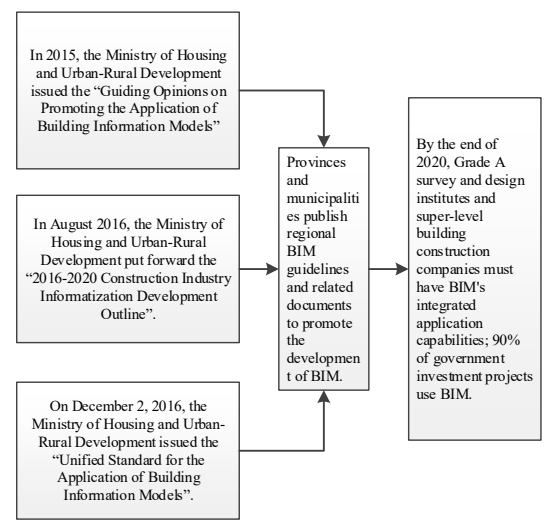

Fig. 1. The Ministry of Housing and Construction's specific guidance on BIM technology

\section{Application development of BIM technology in construction industry}

Construction companies actively build BIM technology platforms and develop application specifications and databases within the enterprise, including the creation, sharing, use and delivery of BIM models. Enterprises expect to use BIM technology to optimize work, improve the overall efficiency of engineering projects, carry out cloud computing, big data collection management and information technology synthesis, improve engineering project accuracy, collision check, improve correctness, establish 4D information model, progress at a glance, establish 5D model, cost management is refined and standardized. Enterprise construction participates in the rapid integration and efficient sharing of information from all parties, with the help of a unified data platform. BIM technology can make future information prices more transparent, and the level of operation and maintenance management is improved.

The future construction industry is the application of BIM. In the field of architecture, the aspects currently involved in the application of BIM technology can be illustrated in Figure 2.

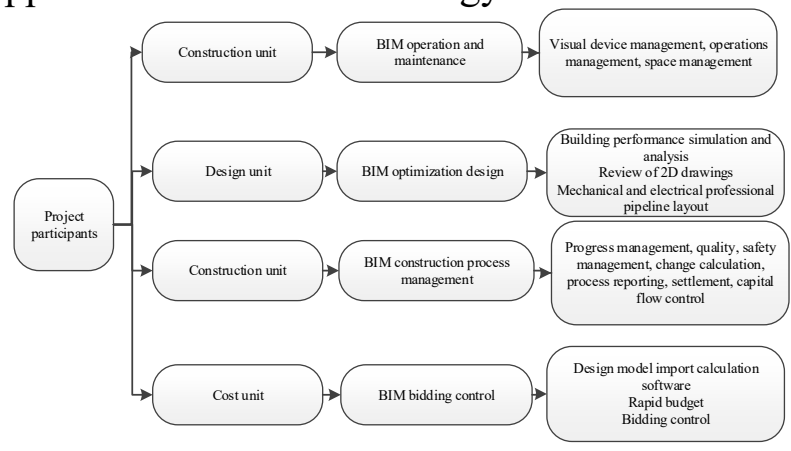

Fig. 2. Project participation by all parties based on BIM technology

\section{Analysis of job and skill requirements for new construction industry in BIM technology}

The interdisciplinary and interdisciplinary coordination and development guided by BIM technology has proposed a new engineering concept, which is the direction of architectural technology innovation. New posts related to BIM technology have opened up a good career prospect for the construction engineering profession. The new occupational and competency requirements of BIM are shown in Figure 3. 


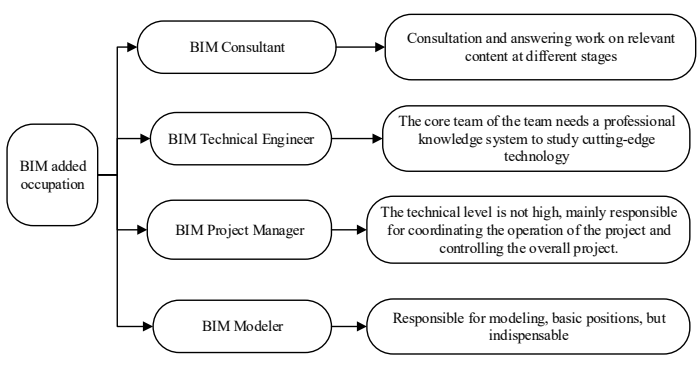

Fig. 3. BIM added occupation and corresponding ability requirements

Undergraduate teaching in applied construction engineering should be adapted to the development of the construction industry. While participating in the technical training and deepening reform of their own personnel, all participants in the construction industry should respond to the skills requirements of BIM technology for graduates of construction engineering.

\section{Application analysis of BIM technology "three-dimensional modeling as core working mode" in applied undergraduate engineering}

\subsection{Comparing positioning of BIM technology training programs in undergraduate colleges of different architectural engineering}

The future of the construction industry is the application of BIM technology. The professional theoretical system and vocational skills training of the undergraduate course of higher education college provide knowledge reserve and skill training for the future engineering and technical personnel of the construction industry, while maintaining the high efficiency and high quality of the construction industry, and serving the national and local economic construction.

The formulation of the talent training program of the College of Higher Education should reflect the employment-oriented, student-centered, and premise of the future development of the industry, and clarify the core competitiveness that students should have after graduation. Different institutions have different training programs, and there are differences in the level of BIM technology. Table 1 compares the BIM technical requirements in the training programs for construction engineering professionals in different undergraduate colleges.

Table 1. Comparative analysis of BIM technology mastering requirements in different undergraduate colleges

\begin{tabular}{|c|c|c|c|}
\hline $\begin{array}{l}\text { Institutional } \\
\text { nature }\end{array}$ & $\begin{array}{c}\text { Research Architecture } \\
\text { Engineering Undergraduate }\end{array}$ & $\begin{array}{l}\text { Applied Construction } \\
\text { Engineering Bachelor }\end{array}$ & $\begin{array}{l}\text { Professional Construction } \\
\text { Engineering Bachelor }\end{array}$ \\
\hline $\begin{array}{c}\text { Training } \\
\text { objectives }\end{array}$ & High-level, composite & Application Type & $\begin{array}{l}\text { Vocational and technical } \\
\text { skills }\end{array}$ \\
\hline $\begin{array}{c}\text { Training } \\
\text { requirements }\end{array}$ & $\begin{array}{l}\text { Expanding } \\
\text { innovation }\end{array}$ & $\begin{array}{c}\text { Application } \\
\text { innovation }\end{array}$ & $\begin{array}{c}\text { Skilled } \\
\text { operation }\end{array}$ \\
\hline $\begin{array}{l}\text { Post adaptation } \\
\text { level }\end{array}$ & $\begin{array}{l}\text { BIM engineer } \\
\text { BIM Consultant }\end{array}$ & $\begin{array}{l}\text { BIM Project Manager } \\
\text { BIM engineer }\end{array}$ & BIM Modeler \\
\hline
\end{tabular}

The analysis shows that in the BIM talent training of undergraduate majors in applied construction engineering, the theoretical knowledge is basically sufficient, and the techniques of modeling and information technology synthesis and optimization require skilled application. Driven by big data, cloud computing, the Internet of Things and the nation's smart city construction, the undergraduate major of applied construction engineering has added the "three-dimensional work core" BIM construction based on traditional skills such as design, construction and project management. Skills such as mold, technical application and project optimization.

\subsection{Undergraduate course system of applied construction engineering supports BIM technology}

The basic relationship between the undergraduate course system of applied construction engineering and BIM technology is shown in Figure 4. The proficient operation of professional software technologies such as CAD, Revite, PKPM, and Glodon is the carrier and core skill of BIM technology. 
The establishment of professional curriculum systems such as foundation, architectural design, structural design, construction, and engineering cost is a BIM technology development, supplement, and support system. The moderate theoretical knowledge of the curriculum system and the enhancement of practical teaching links are the most powerful guarantees for BIM technology.

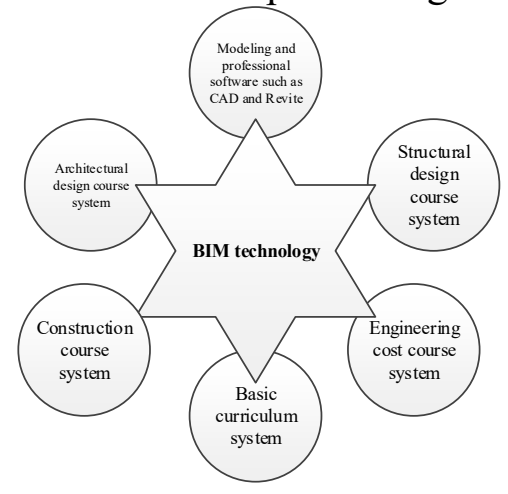

Fig. 4. Relationship diagram between undergraduate BIM technology and curriculum system setting of applied construction engineering

The "three-dimensional modeling as the core working mode" in the undergraduate teaching of architectural engineering is the reform of the graphic course system. This model needs to ensure that the Revite 3D modeling software learns less than the sum of CAD and civil engineering drawing hours. CAD technology will not exit the construction industry for some time to come, students should be proficient in CAD drawing skills. Civil engineering drawing should reasonably reduce the drawing geometry, establish a "three-dimensional as the center" teaching mode, and adopt or compile a new version of the Internet + textbook to achieve network-based teaching and guide students to learn independently.

\subsection{Analysis of core skills of applied construction students and application optimization of BIM technology}

The analysis of the core skills of the construction engineering students in applied colleges is shown in Figure 5. Through the classroom theory teaching system, students can initially possess the first-level core competences of design, construction and project management; through practical teaching links and post-internships, they can initially have secondary core skills; through architecture, architectural engineering, engineering cost The professional teamwork graduation design can initially have the comprehensive skills of BIM modeling technology application optimization.

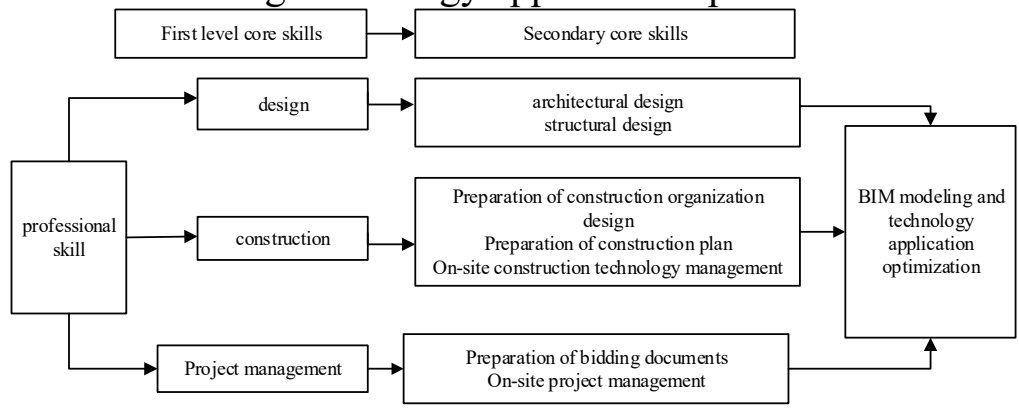

Fig. 5. Analysis of core competence of college building engineering major

\subsection{Construction engineering professional group construction + teaching platform $=$ BIM technology application based on virtual platform}

The construction of the construction engineering professional group and the construction of the technical platform are conducive to the realization of the BIM technology application and the undergraduate professional education 2.0 upgrade based on the virtual platform. Three professional students, including architecture, construction engineering, and engineering cost, form a teamwork model, conduct joint design of BIM projects, and conduct comprehensive inspection and assessment of students' virtual BIM technology through cross-professional and interdisciplinary joint graduation 
design. Promote cross-learning between different disciplines, Internet + technology innovation projects and professional discipline competitions, and cultivate new engineering application talents that are interdisciplinary, interdisciplinary, and theoretical.

\section{Building BIM technology studio to realize innovation and development of BIM technology}

BIM Technology Studio is divided into BIM Technology Lab and BIM Technology Innovation Studio.

BIM Technology Lab explores the construction of BIM technology with "three-dimensional modeling as the core working mode" and explores the full chain, network and openness of deep integration of production, education and research. Collaborative innovation BIM technology alliance, build a high-tech talent training base for construction enterprises, research and feedback teaching, and in-depth curriculum reform. Practice has proved that the cooperation between the research office and the enterprise is prominent, and the goal of BIM technology to serve local economic construction is realized.

BIM Technology Innovation Studio established a new mode of independent and mutual learning, tutor system, school-enterprise cooperation practical engineering case application, selection of competitive competition system, professional qualification examination and certification, stimulating students to pursue high-level, complex, engineering practice ability And multiple target systems for innovation capabilities. School-enterprise cooperation to build a student science and technology innovation platform, BIM technology innovation studio has become the center of students' science and technology activities and the university science and technology innovation project incubation base, and has cultivated excellent Internet + innovation projects.

\section{Acknowledgment}

This paper has been supported by the scientific research foundation project of Yunnan Provincial Department of Education (2014Y386).

\section{References}

[1] R. He, Y. Y. Luan and D. Gao, Research on the Reform of Civil Engineering Curriculum System Based on BIM Talents Training, Journal of Graphics, Vol.38, pp. 102-108, 2017.

[2] D. Miao, Construction of BIM Construction Engineering Drawing Teaching System, Journal of Graphics, Vol.37, pp. 826-830, 2016.

[3] B. Y. Ji, Z. Q. Qi and Z. Y. Jin, Construction Industry BIM Application Barriers and Countermeasures Based on Externality Analysis, Construction Technology, Vol.43, pp. 84-87, 2014.

[4] L. T. He, The current status of BIM technology in the world, Engineering Quality, No.3, pp. 12-19, 2013.

[5] C. X. Zhang, Research on Application Status and Development Strategy of BIM Technology in China's Construction Industry, Construction economy, No.21, pp. 96-98, 2011. 